Nosan, T.M. (2020). Regional features of the design of traditional women's headdresses of the Russian North (Karelia) in the technique of gold and pearl sewing. Actual Issues of Modern Science. European Scientific e-Journal, 6, 2, 5-39. Hlučín-Bobrovníky: "Anisiia Tomanek" OSVČ.

Носань, Т.М. (2020). Региональные особенности оформления традиционных женских головных уборов Русского Севера (Карелии) в технике золотошвейного и жемчужного шитья. Actual Issues of Modern Science. European Scientific e-Journal, 6, 2, 5-39. Hlučín-Bobrovníky: “Anisiia Tomanek” OSVČ. (на англ.)

DOI: $10.47451 /$ ped2020-12-001

The paper will be published in Crossref, ICI Copernicus, Academic Resource Index ResearchBib, J-Gate, ISI International Scientific Indexing, Zenodo, OpenAIRE, BASE, LORY, LUASA, ADL, eLibrary, and WebArchive databases.

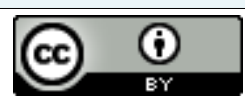

Tatiana M. Nosan, Associate Professor, Candidate of Pedagogical Sciences, Department of Artistic Embroidery, Higher School of Folk Art (Academy). St. Petersburg, Russia.

\title{
Regional features of the design of traditional women's headdresses of the Russian North (Karelia) in the technique of gold and pearl sewing
}

Abstract: The article is devoted to the original types of traditional applied art-gold embroidery and pearl embroidery, in its deep traditions and the widespread of this art in the Russian North. The article deals with the history of the development of the pearl industry in Karelia, provides data on the use of gold and pearl embroidery in products, unique women's hats and jewellery. The author analyses the materials, various techniques, ornaments and colour solutions of Karelian embroidery. According to its artistic merits, embroidery in the North of Russia is the brightest page in the world history of art. A creative approach to the study of folk values and culture makes it possible to rethink and combine folk art with modern trends in modelling and artistic decoration of clothing contributes to the formation of the designer's personality. The article materials are intended for researchers and scientists in cultural heritage preservation.

Keywords: headdresses, pearls, traditional applied art, technological techniques, colour scheme, national features, folk traditions, ornament, clothing modeling, design.

Татьяна Михайловна Носань, кандидат педагогических наук, доцент, кафедра художественной вышивки, Высшая школа народного искусства (Академия). Санкт-Петербург, Россия.

\section{Региональные особенности оформления традиционных женских головных уборов Русского Севера (Каремии) в технике зомотошвейного и жемчужного шитья}

Аннотачия: Статья посвящена оригинальным виАам традиционного прикладного искусства золотошвейному и жемчужному шитью, в его глубоких траАициях и широкому распространению этого искусства на Русском Севере. Рассматривается история развития жемчужного промысла в Карелии, приводятся данные по применению золотошвейного и жемчужного шитья в изделиях, уникальных женских головных уборах и украшениях. Автор анализирует материалы, разАичные приёмы, орнамент и цветовые решения вышивки Карелии. По своим художественным Аостоинствам вышивка Севера России является ярчайшей страницей в мировой истории искусств. Творческий подход к изучению народных ценностей, культуры дает возможность переосмыслить и соединить народное творчество с современными направлениями в моделировании и 
художественной отделке одежАы, способствует становлению Аичности дизайнера. Материалы статьи предназначены Аля исследователей и учёных в области сохранения культурного наследия.

Ключевые слова: головные уборы, жемчуг, традиционное прикладное искусство, технологические приемы, цветовая гамма, национальные особенности, народные традиции, орнамент, моделирование одежды, дизайн.

\section{Introduction}

Karelia is a true treasure trove of artistic folk culture, one of the varieties of which was the traditional art of embroidery. Our task is not only to preserve such a rich artistic heritage but also to revive the past, as well as comprehensively studying the beautiful old folk art to find further ways to develop folk craft, taking as examples the best works that amaze with their simplicity and variety of compositions. Researcher of folk-art M.A. Nekrasova writes that "folk art is the past, living in the present, aspiring to the future with its dream of the unprecedented. It creates the World of Beauty, lives by the ideal of Goodness and Justice, and develops according to its laws. It is the cultural memory of the people, inseparable from the deepest aspirations of our time" (Boøheva, 2008).

Over the centuries, different regions have developed their aesthetic tastes and traditions, as well as their methods of processing materials. However, folk art has never been isolated. Coming into contact with the artistic creativity of the population of neighbouring regions and peoples, it absorbed new features that the masters creatively perceived and processed according to local tastes, customs, and conditions.

Domestic ornamental art reflected the spiritual culture, aesthetic views of its creators. It sang the joy of work and creation, dreams of happiness and beauty. The nature of the northern region was a constant source that inspired folk craftsmen on various topics and forms of folk art. She provided them with the necessary materials.

All these features characterize the features of decorative art, characteristic of Karelian folk art. Embroidery has long been almost the main form of decorative folk art of Karelian women. The embroidered patterns of Karelians decorated clothes, women's shirts, headdresses-magpies, povoyniks, kokoshniks, as well as towels, valances, etc.

These products performed not only a utilitarian function. They formed an essential part of numerous Karelian festivals and rituals, were part of the dowry of the Karelian bride.

Depending on the materials, the Karelian folk embroidery was divided into embroidery with cotton filament, silk, gold embroidery and pearl embroidery. Each of them is characterized by certain types of equipment, its plot, stylistic features. Embroidery was also divided on a territorial basis. The most ancient and striking group was the geometric patterns that decorated the ancient headdresses made of canvas material-magpies. Folk costume and its part - the headdress - are the most massive type of traditional folk art, an integral part of our culture, a witness not only to the national identity of a person. It bears the imprint of the time, the history of the native land, the way of life, the social environment. The desire to preserve and continue the traditions of ancient culture makes us constantly turn to folk art, so the following tasks are faced by bachelor artists in the course of training: 
- study of the traditional artistic heritage of the ornamented objects of peasant art stored in the Karelian State Museum of Local History, headdresses (aesthetic content of headdress forms, laws and rules of composition, ornamentation, embroidery methods, fabrics, shape design, dimensions, pattern, colour);

- further improvement of products of applied and folk art, taking into account the traditions and knowledge of various techniques of embroidery of headdresses;

- preserving and reviving the traditions of folk-art craftsmanship, which is a life-giving source for modern people in the space of decorative and applied art.

Thus, each craftswoman sought to achieve the utmost expressiveness in the design, decorative processing, introducing the inherent artistic handwriting into the created products, relying on the centuries-old traditions developed by the masters of previous generations. Folk art is the result of collective creativity, its characteristic continuity coming from the depths of centuries, the influence on the creative process of future generations, who must preserve this tradition of studying, revising, performing and preserving new products of applied and folk art.

The diversity of Karelia's cultural heritage is a unique expression of human achievements and serves as an irreplaceable source of spiritual and intellectual wealth.

The problems of preserving cultural values in their aesthetic and historical significance, for the sake of modern and future generations, have always been the subject of research by such scientists, politicians, art historians, and specialists of traditional applied art of public figures in Russia as I.E. Grabar, D.S. Likhachev, M.V. Lomonosov, A.V. Bakushinsky, I.Y. Boguslavskaya, N.P. Bozhieva, N.P. Burmistrova, L.A. Dinzes, A.P. Zhuravleva, N.M. Kalashnikova, S.V. Lebedev, E.E. Knats, N.T. Klimova, A.P. Kosmenko, G.S. Maslova, N.A. Rodionova, M.A. Sorokin, V.A. Faleeva, and others.

The traditional costume of the Russian North (Karelia) began to take shape in the 12th and 13th centuries. According to scientists (I.Y. Boguslavskaya, G.S. Maslov, A.P. Kosmenko, N.M. Kalashnikov, M.N. Mertsalov, M.A. Sorokin, L.F. Kislukha, and others), the Russian ethnos was undergoing an intensive process of formation during this period. One of the elements of the nation formation process was the clothing of the ancient northern peoples (Russians, Karelians, Veps, Finns). The Russian northern costume was quite peculiar. It was noticeably different from others and successfully corresponded to the way of life of the people.

In the process of research analysis of the state of artistic heritage, festive women's headdresses, their aesthetic content of forms, laws and rules of compositional solutions, ornamentation, embroidery techniques, fabrics, designs of shapes, sizes, patterns, colours. Taking into account the traditions and professional training in this field, regional-historical, informational-informing, instructive-practical, artistic-technological, practice-oriented research methods are used in the museum, which provides a unique opportunity to study authentic works of traditional applied art in the field of artistic embroidery.

This article examines the history of the origin and development of the gold and pearl art centres; technological features of the most common types of seams, with detailed information about their performance in the traditional applied art of Karelia.

In the sections of the article, the technology of embroidery design of girls' and women's headdresses, reflecting the traditional art of the Karelian region, is given. The principles of creative reinterpretation of the source, which consist of the integration of folk traditions into 
modernity, are proposed. The application presents a unique illustrative material (historical samples of works of folk masters of traditional and applied art).

This experience of understanding methodological and theoretical aspects is of great interest to artists-bachelors, masters, postgraduates, teachers of art universities, additional education, for a wide range of readers, creative workers engaged in artistic design and decoration of textiles, as well as for those who love and are interested in folk art.

\section{History and technological features of traditional embroidery of women's headdresses of Karelia on the examples of ancient samples}

As in all Russian provinces, the Olonets women's costume was complemented by specific headdresses on a rigid basis, such as a kokoshnik divided into girls' and women's ones.

The girl's costume differed from the suit of women of other age groups by the headdress. The girls were supposed to wear a headdress that revealed their hair above, which allowed them to see the braid running down their back. Maidenhair was perceived by the peasants as a symbol of beauty, innocence, and marriage opportunities. Many maiden headdresses that were previously considered festive: "golovodets", "pocholok", "crown" and others at the end of the 19th century turned only into bride headdresses.

The products of applied and folk art undeservedly forgotten in our country acquire their value and superiority over industrial designs. No wonder people have always appreciated manual work as a source of emotional spirituality. Among such well-known types of needlework as embroidery, the headdresses design with embroidery and knitting of pearls occupy a special place. The headdress in the form of a wreath, bandages of a ribbon, "pocholoks" from brocade, a braid from damask fabric, strips of calico with rich sewing with a gold filament, typical for the northern regions, were made wide, on a dense basis. They were sometimes decorated with a hemline or duckweed made of river pearls, chopped mother-of-pearl, or beads that descended to the forehead.

The Karelian masters were perfectly skilled in gold and pearl embroidery, which came from Pomeranian nuns (in some Karelian territories) (Nosan, 2006). As very expensive and highly valued needlework, these original types of embroidery had the character of craft production. There is information that at the beginning of the 18th century, Olonets pearl "ochels" were sold in large quantities at the fairs of Novgorod. Headdresses were very expensive, so they were carefully preserved in families and passed down by inheritance. As headdresses, women of the northern provinces wore kokoshniks and kokoshniks-assemblies.

The kokoshnik, which was used mainly in the Russian North, in the north-eastern and central provinces of Russia, occupies a special place among women's headdresses (Figure 1). The name of this headdress is interesting and unusual, going back to the ancient pagan cults of the Eastern Slavs, their totems-protectors and guards from evil spirits. Such totems were those animals and birds with which human life was most closely intertwined: deer, elk, swans, ducks, roosters, chickens. It is their images that can be seen in the patterns of the oldest counted embroidery, and the contours and individual details of the figures in headdresses. "Kokosh" "rooster and chicken" - is the literal translation of the name of this headdress, which originated in the Russian North, which had a deep semantic meaning. It symbolised happiness and unity in marriage, the warmth of the hearth (red rooster-fire), carried the idea of fertility, and with it the 
infinity of the cycles of life, asserting the value of human existence (Kosmenko, 1990). "The importance of the rooster and the hen in the wedding ceremony was great: one of the dishes of the wedding table was made of chicken, and a rooster dressed up and decorated with coloured ribbons was brought to the groom's house" (Nosan, 2006). That is why in wedding headdresses, a specific preference was given to the kokoshnik. In front of the kokoshnik, a pearl or beaded underside was usually hung - a net consisting of several pearl assemblies, woven to hold beads, pearls, semi-precious stones, and glass inserts.

The podniz (a net or fringe of beaded, pearl filaments at the ancient female headdress, descending to the forehead and temples) was attached to the eyeglass and covered the woman's forehead almost to the eyebrows (Figure 2). On the side near the ears, cassocks, or duckweeds, could be attached - strands of pearl or beaded grains with filaments of braided metal (gold or silver) lace (Figure 3).

Until the 1920s, in Petrozavodsk, Povenetsky, Pudozhsky and Kargopolsky uyezds and the village of Kizhi, the festive women's headdress was a one-horned kokoshnik, on a solid base, with a flat upper part protruding above the forehead in the form of a blunt horn. The decoration of the kokoshnik consisted of river pearls, beads, mother-of-pearl dies and gold braid. From the lower edge to the forehead descended several flounces - "lattices", "one under the other", made of small river pearls or beads (Figure 4). These kokoshniks were worn with silk sarafans, and when leaving the house, they wore handkerchiefs made of silk or white calico with a rare small pattern embroidered with green filaments. The handkerchief was folded at the corner and pinned under the chin. This headdress was common in Kargopolsky uyezd of Olonets province. Such kokoshniks had small blades that covered the ears, the back of the head-a strip of fabric on a solid base, sewn on the back, and the underside-a pearl or beaded mesh descended to the forehead to the eyebrows or slightly raised above it. Kokoshniks were decorated with gold embroidery, beads, pearls, mother of the pearl. They were usually worn with a handkerchief folded on the corner. The handkerchief was pinned under the chin or, crossing under it, tied behind the neck. Such kokoshniki were common in Olonets province (Nosan, 2006).

The second type is in the cylindrical cap form with a flat oval bottom (Figures 5, 6, 7). This cocoanut of the north-west did not have sewn-on blades and a headpiece. It was usually made of braid, decorated with gold embroidery, glass in the sockets, beads, pearls, and had a small base of chopped mother-of-pearl. Around the kokoshnik, along its ochelye, a folded handkerchief was tied with a ribbon, whose ends descended to the back or were fixed on the crown of the head, crossing at the back of the head (Figure 8). "Strung kokoshnik... sewn taffeta with silver lace..." - such an entry can be found in the acts of legal life of ancient Russia, dating back to the 18th century (Historical and legal acts of the Olonetsky Krai, 2010).

Kokoshnik assemblies are a headdress on a solid base (Fig. 9). The assembly was made of brocade, braid, silk, velvet, embroidered with silver or gold filament on cardboard.

A specific feature of such an assembly was a wide ochelye and a cone-shaped elevation on the crown, laid in front with vertical and dense bolsters-bores. At the back, the assembly was tightened to the top and decorated with a wide bow with long ends descended to the back (Historical and legal acts of the Olonetsky Krai, 2016). The assembly's eyeglass was ornamented with beads, coloured glass in a metal frame, replacing precious stones. Sometimes a beaded or pearl net-podniz that covered part of the forehead, was attached to the assembly. The upper part of 
the cocoanut is completely sewn with gold filaments. The front is laid in fan-shaped folds. The ochelye is decorated with a pattern of large stylized flowers - tulips, decorated with pearls, mother-of-pearl dies, faceted glass in metal sockets, and openwork podniz.

Kokoshnik assemblies of "borushki" were festive headdresses of young women of the Arkhangelsk province in the 19th century married. They were made by professional craftsmen from factory fabrics using white beads, foil, glass, chopped mother-of-pearl and river pearls in the ornamentation.

To perform the ornamentation of river pearls used belle. This is a twisted white rope, cotton or linen, which is sewn on the material (linen, silk, velvet) in two or three rows, according to the preliminary marking. And in the hollow between the rows, pearls are already sewn ("planted"). The drawing is clear, smooth and convex. Sometimes the bel was laid out in one row, but then the impaled stones could unevenly hold the line, so the single-row bel was used only in a very dense pattern, e.g., in the Kargopol kokoshniks. The most specific ornaments were floral, as well as images of birds. The forms of headdresses for the sarafan complex were different, e.g., kokoshniks in the form of a cap, with a high, elongated ochelye with blades decorated with gold embroidery, covering the ears (Kargopolsky uyezd of the Olonets province). Dressing, dressing with a silk "ribbon" (Figure 10). Girls' and women's headwear. The bandage was a strip of cloth, most often made of brocade, with strings sewn at the ends, which fastened the headdress at the back of the head. The front part of the headdress was decorated with beads, pearls, and gold embroidery. The nature of the jewellery depended on the material wealth of the girl (Nosan, 2006).

On ordinary days, the girl wore a kerchief folded like a ribbon tied around her head. Festive girls' headdresses were varied in shape, material and decoration, consisted of a rectangular strip of silk, often crimson, on a solid base (birch bark, several layers of paper, fastened with bread glue), with ribbons on the back of the head. In the Arkhangelsk province in the second half of the 19th century, the most common festive girlish headdress was a bandage made of crimson silk (damask) or calico on a solid base with wide ribbons (up to $85 \mathrm{~cm}$ long) that went down the back almost to the waist. On the front side, above the forehead, a narrow strip of braid was sewn, and above it, gilded filaments were embroidered with figures of birds or another strip of the widest braid. These headbands were worn with silk and festive sundresses. In the Olonets province (the second half of the 19th century), the festive headdresses of girls of marriageable age were "bandages", also called "ribbon".

"Bandaging" is a girl's headdress in the form of a hoop made of birch bark, cardboard or quilted in several rows of fabric, covered with brocade, silk, calico, pestryad (fabric with a pattern formed in the process of weaving, using filaments, or fibres of different colours (as opposed to the pattern formed by dyeing the finished fabric), with ribbons tied behind (Figures 11, 12). The height of the dressing is from 5 to $22-25 \mathrm{~cm}$. High bandages had the form of a truncated cone, tapering upwards (Historical and legal acts of the Olonetsky Krai, 2016; Sosnina \& Shangina, 1998). Podniz is a net on horsehair made of beads or pearls, which descended on the forehead or rose above it, forming two or three arcs. Podniz, the grid consists of several pearl collections. Two wide ribbons or one wide strip of brocade (up to $25 \mathrm{~cm}$ ) decorated with gold lace, braid, fringe, etc. were attached to the dressing back.

The bandaging is an old maiden's headdress. The term was known in the 16th and 17th centuries. Bandages in the 18th and 19th centuries were a festive headdress for girls of 
marriageable age. It was worn only on special holidays: on Yule parties-games, on spring and summer festivities. "Bandages" consisted of a long rectangular strip of crimson damask (length $45-48 \mathrm{~cm}$, width $7-8 \mathrm{~cm}$ ) on a solid birch bark base, with ribbons on the back of the head. The ribbons were tied under the braid, and a wide rectangular strip of silk was attached above, which descended to the back. The front part of the headdress was usually embroidered with gilded filaments (Figure 13). The betrothed bride attached to the bandage a small circle - "temnik", embroidered with gilded filaments on one side.

"Konura", or "koruna", is the headdress of a betrothed girl, is associated with wedding ceremonies in the northern regions of Karelia, in the Arkhangelsk province. The bride wore the "konura" on her head not only on the wedding day but also on holidays (Nosan, 2006; Sosnina e Shangina, 1998). 'Konura' - an openwork roller on a solid base-a hoop made of birch bark or pasted in several rows of cardboard, glue board, covered on the outside with a gold or silver braid, decorated with beads, beads, and on the inside-with calico or stuffing (Figure 13). An openwork roller made of taped canvas and a string of beads sewn on it was attached to the hoop. Then beads, coloured glasses in a metal frame, oval medallions with enamel paintings, pendants made of beads, brooches, buttons, and flowers made of starched canvas were attached to the canvas. At the back of the kennel was tied a wide bow of silk fabric, the ends of which fell below the shoulder blades. In the northern regions, the "konura" was worn over a bandage sewn from a braid with ribbons or blades running down the back (Figure 14).

"Crown" is a girl's headdress. The Onega and Pudozhsky openwork crowns, with a podniz, differ in refinement. The underside was made of elastic horsehair strung by pearls to make the bend undulating. On the "crown", the pearls were strung on a strong filament (or hair), which was applied according to the pattern and attached with another filament. The "crown" also was decorated with a bright bugle. In the Kem district, brides wore a special ancient headdress in the form of a crown made on a solid base (Figure 15). The band of this headdress ("podchelok") was narrower comprising the girl's bandage. A 'crenate corolla' was attached to the upper side of the band. From the back of the head, from the edge of the band, a wide rectangular strip of brocade or silk freely descended to the back (Figure 10).

The headdress was tied with ribbons under the braid. The front side of the "podchelok" was decorated with gold embroidery, pearls and beads, and metal-rimmed glasses that imitated stones (Sosnina \& Shangina, 1998).

"Butterfly" earrings, i.e., earrings made of pearls, beads, chopped mother-of-pearl, metal are a metal rod with two blades on the sides of beads, pearls, mother-of-pearl, strung on horsehair or thin wire, which are attached to the end of the rod of a metal teardrop-shaped pendant, braided with a mesh of pearls (Figure 17). The side blades of the decoration resemble butterfly wings (Sosnina \& Shangina, 1998). "Butterfly" earrings were the most common jewellery in the Russian north. They were worn with a festive costume, silk, brocade or velvet sundress, a shirt, a smart shower jacket, a crown or a kokoshnik decorated with pearls.

"Pochelok" ("podchelok") was also called a crown with five rays- fences, cut out of thick cardboard, pasted on the front side with a starched canvas, and on the wrong side painted red (Figure 18). On the front side, the pattern is laid out with a thick hemp cord with white beads sewn on it (or two rows of thin cord-beads in the middle), i.e., multi-petalled flowers with a large core. The petals (their middle) were filled with birch bark (cardboard), sheathed with copper bits, 
cantilevers, huge pearls and mother-of-pearl (Nosan, 2006; Sosnina \& Shangina, 1998). Copper and brass leaves, attached to the stems of the cantilever, decorated the crown. The crown was sewn on a narrow but dense strip of fabric, the ends of which were tied under the braid. At the back, a wide strip of silk or brocade with gold lace, ribbons, and fringe at the end was attached to the "podchelok".

"Podchelok" is an ancient maiden headdress dating from the second half of the 18th century. According to the observation of G.A. Grigorieva, in the collections of Russian museums, there are only two similar headdresses, which are stored in the Karelian Museum of Local Lore in Petrozavodsk. The front part (ochelye) on a solid base, rectangular in shape, with a curly zigzag cutout along the lower edge. A narrow strip of silk braid is sewn on the back, on which three long strips of ribbon on a hard lining are attached. The glasses and ribbons are decorated with a stylised pattern of complex geometric shapes, rosettes and diamonds, made in the technique of sewing small transparent beads ("pearls") on white, metal sequins and glass beads. On the wrong side of the ochelye, the plank and the ribbons are sewn with cloth-printed linen fabric. References to such headdresses also exist in the old scientific literature, e.g., at V.F. Miller, in his description of the collection of the Dashkovsky Ethnographic Museum, where peasant clothing of the 1870 s and 80 s was plentifully presented: "Girls in the old days wore "podchelok" on holidays, now the head is removed with ribbons "podbirushki" and "bandages".

Since the 1880s, the girl's headdress "circle", which was also called "rim", was widely distributed in the Olonets province.

"Circle" is the headdress of a betrothed girl of the Olonets province of the Kargopol uyezd (Figure 19). As a girl's headdress, it was a bandage 5-6 cm wide, made of a handkerchief with a narrow strip of the paper lining. The bandage was wrapped around the head in such a way that the top of the head remained open, and the ends of the handkerchief were tied over the forehead. Sometimes in the Olonets province, a circle was called a headdress under the name "rim" (Sosnina \& Shangina, 1998).

It was made on a solid basis in the form of a hoop covered with calico. On the front part of it, above the forehead, openwork nets of pearls or beads in the form of several flounces were attached one above the other. At the back of the head, through a small loop, one wide ribbon was filamented or several narrow multi-coloured ones, which were called "flags", were attached to a small twig with a loop, which was more typical for brides.

Festive "circles" were made of red silk and embroidered on the upper part with gold filament. The band of everyday "circles" was sewn from calico, pestryads; the top was trimmed with braid. When leaving the house, the "circle" was usually tied with a handkerchief wrapped in a tourniquet or a strip of the braid.

"Podcholok" is an ancient and rare, unique in museum collections, the festive maiden headdress of the 18th century of Olonets province, Kargopol district. It was found in the city of Kargopol in a dilapidated state. From the back of the headdress, two genuine straps open for attaching ribbons made of beautiful silk braid on a red cloth lining, ending in two loops. The "podcholok" is made of wool, silk, linen, cotton fabrics, paper, white, beads, sequins, metal and glass buttons (Figure 20). Beading. The ochelye is 27 by $19 \mathrm{~cm}$, the length of the ribbons is 49 cm (Grigorieva, 2002). 
A handkerchief is a square cloth made of wool, silk, brocade, linen or cotton fabric, of various sizes, from small ones that only cover the head or shoulders, to large ones that wrap the entire figure of a person. The headscarf was an integral part of the girls' and women's headdress and an independent headdress, as well as a neck decoration for women and men (Figure 21). In the 19th century, it became part of many headdresses. It was worn with a kokoshnik, magpie, and povoynik. In the late 19th and early 20th centuries, the headscarf became the main headdress tied in many ways. In the Kargopolsky uyezd of the Olonets district, handkerchiefs with gold filament, gilded spun silver, whipping, and silk filaments embroidered on the corner of floral patterns were very popular (Figures 22, 23). The headscarf was used to decorate a festive costume and was considered a great family value (Nosan, 2006).

"Povoynik" is a traditional headdress of a young woman. Its purpose is to cover her hair. According to ancient beliefs, the hair had magical powers. This power was given to women by Mother Earth. When a woman married, she became a member of someone else's family, and in order not to bring misfortune to her husband and his relatives, she had to carefully hide her hair.

Pomor "povoyniks" (from the Old Believers) sewed in the form of a soft cap, completely covering the hair, braided in two braids and laid on the head. It is simple in cut: an oval crown was cut out (from the Old Believers of Zaonezhye) and a "band" was sewn perpendicular to it, which bifurcated from behind, forming "wings"; laces (braid) were sewn to them, with which it was tightly attached to the head. This is one of the oldest headdresses in Karelia (Figure 24).

The "povoynik", which was used on weekdays, was made of canvas, calico, satin, calico and other inexpensive fabrics. Festive povoynik was sewn from crimson or blue velvet, silk, brocade, cashmere (Grigorieva, 2002). It was decorated with gold embroidery, beads, pearls, glass beads, braid, etc. in the upper part.

In the 19th century, real gold and silver filaments were replaced by gilded and silvered copper. River pearls were gradually replaced by cheaper beads and artificial pearls. The motifs of gold embroidery on the povoyniks are fantastic flowers and stylised double-headed eagles: the tree of life was embroidered with pearls. The soft depth of the velvet and the matte gloss of the ornament enhanced the decorative effect, revealing the features of the pattern. Especially interesting are the Pomor povoyniks - "latushki", decorated with river pearls from the northern rivers of Karelia. In the 18th and 19th centuries, gold was sewn on a map (the base is birch bark) (later cardboard), sheathed first with woollen filaments, and then with gold, silver, and pearls (Figures 24, 25). The upper part was embroidered with gilded and silver filaments and a thick cord around it, placed on the wrong side (Figures 26, 27).

"Povoynik" was always covered with a handkerchief: silk or cashmere on holidays and canvas, calico, or satin on weekdays. It was considered very indecent to go out on the street in one raincoat, without a headscarf, or to be at home in front of strangers, and sometimes at home (Nosan, 2006). The methods of tying the scarf were different and depended on the local tradition. The first method: the handkerchief was folded diagonally or twice around the perimeter, put on the head in such a way that part of the ochelye was visible. It was pinned or tied under the chin. The second method: the handkerchief was folded diagonally several times so that a ribbon was obtained. It was laid in a spiral, crossed on the back of the head, laid on the sides or tied with a bow on the crown. Girls' headdresses were the main decoration of the young Karelka on weekdays and holidays. They reflected the ethnographic features of the Karelian people. 
Headdress "Magpie with Sderikha" - the oldest female headdress of the Olonets province (Figure 28). "Sderikha" is a kind of cap made of homespun canvas, in the upper part with a "crown" in the form of a hoof. "Magpie" - the second part of the headdress - was worn on "sderikha". "Magpie" - the most ancient headdress of married women - was usually made of calico, silk, velvet on a canvas or calico lining. It was sewn from 3 parts: a low triangular ochelye, embroidered with silver or gold filament, decorated with beads and beads; triangular side wings; the back part is the tail (a cloth covering the crown and the back of the head) (Nosan, 2006). All parts were connected so that the headdress took the form of a cap with a rectangular oval top. If the "tail" was short, then it was almost completely sewn together with the "wings". If long, then a significant part of it descended to the shoulders.

Along with the "magpies" in the form of caps, "magpies" were also common, not completely sewn connected, there were only eyeglasses with a "tail" and "wings" with an eyeglass. Such "magpies" in a flattened form resembled a bird with a long tail and triangular wings located on the sides. Ordinary "magpies" were made of pestryad and calico. Old women wore "magpies" with white or sparse black embroidery. "Magpie with Sderikha" was distributed in Kargopol, Povenetsky, Pudozhsky, Petrozavodsk and Vytegorsky counties in the middle of the 19 th century.

In addition to the "magpies", the Karelians also wore caps (Figure 29). The cap - the headdress of the bride and the young woman, in its appearance was close to the "magpie", and differed in that it had the shape of a circle and was embroidered with gold filaments. Holiday caps were different from everyday ones. Karelian caps, which were worn by older women, were made of silk, half-wool, woollen fabric lined with canvas and calico. The upper part of the cap was stitched, connected in front and along the bottom line was processed by "obtachka" (a cut detail used in sewing for finishing cuts and cutouts of textile and leather products), the back of the cap was tied with a satin ribbon (Nosan, 2006).

By the beginning of the 20th century, women wore a "tattoo" - a "skolok" similar to the Arkhangelsk one (Figure 30). In the dictionary of V.I. Dal, an explanation is given: "a tattoo, a kind of cap, a variety of headdress; the same for merchants: a silk handkerchief with lace, artfully tied and pinned; a hole pattern, a stencil, for a tattoo or rash pattern." For several years, the most valuable material was collected bit by bit, and a unique female headdress was restored (Grigorieva, 2002).

Regardless of the colour of the "couple" (jacket and skirt), the "nakolok" were sewn red, scarlet, crimson, burgundy, pink - in a word, a reddish shade. It is interested in the wedding "nakolok" worn by the bride when she was surrounded after removing the wax wreath. Traditionally, they put it on behind the ears, tightening it from behind and tying it on a string (or ribbon), the ends of which were hidden under the cap. The wedding "nakolok" of the masters was made of "bursa" - a silk Persian fabric, shiny and noisy. For the rich, the "nakoloks" were made more difficult, with the figure stitched, and for the poor, it was easier. The cap was matched with a cotton lining. The "nakolok" was embroidered with beads, beads, glass beads. Lace was only used for those who were poorer.

Thus, the wedding headdresses and headscarves were particularly beautiful. They were sewn with gold and silver formed an essential part of numerous Karelian festivals and rituals. They were part of the dowry of the Karelian bride. According to the beliefs of distant ancestors, it 
believed that an embroidered ornament containing magical symbols and images plays the role of a kind of amulet.

\section{Pearl sewing in the traditional applied art of Karelia}

Pearl mining, as reflected in the church books, was carried out in Karelia, in the north of Russia, in the 9th and 10th centuries. With the developed water system of Karelia, most of the villages were located on the banks of rivers and lakes. In the 15th and 16th centuries, pearls were mined in the rivers of the Kerets region, in the Kemi region. "In the 17th century, pearls were known in the rivers of Karelia, the Kola Peninsula, and were found in the rivers of the Arkhangelsk, Vologda, Leningrad, and Kirov regions" (Grigorieva, 2002).

Historical evidence suggests that the extraction of river pearls, of which there were a lot, was the main source of income for the local population. It is interested in historical documents indicating that Peter the Great decree was preserved. According to them, specific officials were sent to the Russian North for the extraction of pearls. They were charged with the duty to hire 'hunters' (volunteers) for work, but if there were no such people, then "take them into bondage at their discretion" (Fersman, 1954).

In 1721, Peter the Great issued a decree on the regulation of the pearl industry, as production began to decline sharply due to the mass destruction of shells. People blocked the rivers: Megrega, Olonka, Povenchanka, Kem, which were shallow up to 1 meter deep, and then forced their children 7-12 years old to collect pearl shells. It led to a reduction in pearl production since all shells were collected, not selectively, opened and discarded. In the 19th century, the pearl fishery began to disappear in Karelia, so taxes were imposed on its production. After that, pearl shells began to be selectively caught with the help of a birch-bark telescope. This led to a reduction in pearl production. While on the raft, the pearl diver lowered a birch telescope into the water, selected the right huge shell, took a pole with an iron hand on the end, lowered it into the water and through the pipe with an iron palm raised it through the pipe to the surface of the raft.

Pearls in Russia have always been treated with specific respect. It was obtained only in a joyful mood, not allowing abusive words and quarrels. In the 19th century, pearl seekers went fishing necessarily after the bath, wearing clean clothes and receiving absolution from the priest, such as the tradition of successful fishing (Nosan, 2009).

On the eve of the 20th century, A. Khrebtov wrote in his study The Situation in the Pearl Industry of Russia, "... Russian pearls in general, and especially those extracted in the Kem district, are very good in color, luster and shape” (Khrebtov, 2017).

In Karelia, pearls were mostly silvery-white or bluish shade. Pearls were sewn especially festive women's headdresses-crowns, which received the name "zemchugat" from Karel. The zemchugat consisted of three parts: a valance, a "podniz", and a wide ribbon attached to the valance from behind. Young married women to this headdress added a velvet povoynik, embroidered with gold.

The ability to string pearls required painstaking work and great artistic skill. The embroiderer prepared the drawing in advance, then, having drilled a hole in each pearl strung them on a cord, hair or metallic filament and laid out the pearl filaments according to the prepared drawing. 
An ornament made of pearls consisting of rosettes stylized waterfowl and plants (branches, shoots, flowers, trees) covered the entire surface of the headdress as if emphasizing its special significance and solemnity. The torment was worn by the girl at the moment of the main event in her life, e.g., the wedding day, as it was proof of her well-being. The basis for embroidery was silk, velvet, and other fabrics. The forms of northern headdresses, despite the names that unite them, were very diverse even in the surrounding areas. The favourite decorative materials used in the ornamentation of northern headdresses were white beads, foil, glass, chopped mother-ofpearl and river pearls.

Pearls were highly valued, and the documents and samples that have survived to our time show the widespread of pearl sewing in the Russian North and its deep traditions. Until the 17th century, this art developed mainly in boyar, princely palaces and monastic workshops, but it was especially widespread in peasant sewing - women's and girls' headdresses, bangs, headbands, kokoshniks, "korunas". It was believed that the more rows of pearls in the "podchelok", the richer the bride.

In 1897, in the Olonets Provincial Gazette, in the article Geographical and Historical Description of the City of Kargopol, they wrote, "Girls and women undress in headdresses, the former has a certain kind of wreath, covered with pearls, and called after their "koruna", instead of a necklace, they have a "velvet" or "naborshnik" like a tie, and above the "velvet" atop two inches wide is tied lying; a "gribatka" on the shoulders, and all this, except for the "naborshnik", is tied with pearls. The woman's head is covered with a cocoanut covered with pearls. Some of them have a price of more than a thousand rubles" (Olonetsky gubernskie vedomosti, 2010).

Pearl sewing was in different ways. Most of the ornamental compositions of pearl embroidery were contoured, graphic. Pearls on the contours were sewn with a specific technique. A string of pearls was laid out on the cords sewn in two rows. Each pearl was attached with a cross-stitch. Unique is the openwork slotted pearl embroidery used to decorate maiden crowns and rizas (oklads) for icons. Pearl embroidery was complemented by the decoration of motherof-pearl dies, mirror and coloured glasses, precious stones and other materials. Karelian craftswomen perfectly mastered gold-embroidery and pearl craftsmanship. These original types of embroidery, very expensive and highly valued needlework, had the character of craft production.

In the early 17th century, Olonets pearl "ochels" were sold in large quantities at the fairs of Novgorod. In the 20th century, pearl embroidery was preserved in Olonets county (Sudalitsa Village, Kokshigora Village, and Olonets city). Karelian pearls - uneven white, black (greyishmatte), pink. In the rivers that flow into Lake Paanojarvi, pink and black pearls were caught, which were sold abroad. Customers brought pearls to the craftsmen, and they made headdresses - festive, wedding. Beads of various colours, from tiny, $1 \mathrm{~mm}$ in diameter, to large glass beads, were also sold on the provincial market. White beads were used to replace pearls - either they completely replaced the more expensive material from the headdress, significantly reducing its cost, or they were combined with pearls in different proportions.

Thus, the products of the Olonets craftsmen enjoyed great fame, they were able to cut pearls with a specific skill, make necklaces, podnizs, earrings, pendants and wedding maiden headdresses (zemchugats) on which pearls meant for the bride the purity and innocence of a girl entering a new stage of her life. 


\section{Technological techniques of gold embroidery in the design of women's headdresses by the masters of the Russian North - Karelia}

Gold embroidery with metal gilded and silver filaments was also very expressive, and the masters who performed it were called gold embroidery. Gold embroidery decorated the clothes, vestments of the clergy, items of church utensils, headdresses-kokoshniks, povoyniks, which had the form of small oval caps. In southern Karelia, the thieves sewed from velvet, and in the north-from silk. They were the property of wealthy peasants, distinguished by expensive and masterly embroidery, so they were very cherished, passed down from generation to generation and worn only on big holidays. The decorative effect in gold embroidery was achieved using a variety of different techniques and materials. Sewing was carried out with metal drawn to gold or silver filaments or spun filaments. Filaments were also used in the form of a narrow thin strip of the precious metal-to beat, in the form of a thin wire twisted in the form of a spiral - a rope.

The embroidery technique is a rather complex process: after receiving an order, the craftswoman cut out drawings from cardboard, attached the material to the embroidery frame, laid out the cut patterns on the fabric and embroidered with gold or silver spun filament (smooth technique), so that the cut patterns remain under the embroidery, and the pattern turned out convex. The ornamental motifs on the gold-embroidered povoyniks are vegetable (trees, flowering bushes, sometimes with birds on the branches), made in rounded curved contours of sewing.

A specific feature of gold embroidery is the seam - "in the middle". The metal filament was superimposed on the fabric and attached to it with small stitches with a thin silk or linen filament in the colour of gold, silver or colour contrast, depending on the artistic task. Goldsmiths owned a large stock of various patterns-attachments that create additional geometric shapes on the sewing surface under colourful names: "berry with a stalk", "simple berry", "coccyx", "money", "rows", "fence", "feathers", etc.

Expensive imported velvet, silk fabrics, and fine muslin were used as a background for gold embroidery. The embroidery was complemented with pearls, precious stones, gems, gilded ornamented plates, small plaques, and sequins. Ornamental compositions of gold embroidery include plant motifs, images of birds, animals and fantastic animals. The festive kokoshniks were specially decorated. The characteristic of gold embroidery was the outline of the pattern along the contour with small openwork loops.

A diversity of women's headdresses always completely covered the hair (according to popular beliefs, they had magical powers). To go bareheaded was considered a disgrace, a sin, for a married woman. The nature of the headdress reflected not only family but also social and property status. The technique of sewing with gold filaments is significantly different from the usual embroidery. The gold filament is difficult to filament through the fabric since the spun gold would wear out, and the dragged one would not lie flat on the surface of the fabric. Therefore, as a rule, sewing with gold is one-sided. Metal filaments are most often reinforced according to the pattern on the front side of the product and are rarely used as a normal working filament for sewing "on the opening".

The sewing technique with gold and silver is very diverse, but the diversity can be reduced to three main seams. There is a cast (or forged) seam, seam "in-split" and "in-attachment". 
A "cast seam" is a smooth seam in gold (Figure 31). At the beginning of the work, the gold filament is passed with a needle from top to bottom through the fabric near the edge of the embroidered form (cardboard or flooring) and fixed. Next, "in-attachment" sewing is used, in which the gold filament is superimposed in parallel stitches on top of a defined contour (Nosan, 2006). Each stitch of gold filament is attached along the sewing borders to the fabric with a twisted silk or cotton filament attached. A needle with this filament is pricked out at the edge of the shape, grabs the gold filament and pulls it into the same hole of the puncture. The golden filament is transferred to the opposite side of the motif, and everything is again repeated. Stitch to stitch are laid very tightly, without gaps, but also without overlapping.

Horizontal figures are embroidered from left to right, i.e., the superposition of stitches goes from left to right, and vertical ones from bottom to top. At the same time, you need to pay attention to two important points:

- in horizontal figures, when the stitches are placed vertically, the lower part of the stitch is tightened more strongly, and the upper part is smaller. And accordingly, the right side of the attachment is tightened more than the left with a horizontal arrangement of stitches;

- when embroidering a horizontal shape, the needle is pricked out to the right of the gold filament, wraps around it and returns to the same puncture hole to the left of the gold filament. Accordingly, in vertical forms, the needle is pricked out from the upper side of the gold filament, and returns from the lower, i.e., the needle always makes a movement back relative to the direction of applying the gold stitches.

On the wrong side, the filament stitches are attached in the form of eights (Figure 32). It is very important to feel the filament tension. The gold filament stretches on the wrong side, just a little bit on the form borders. When embroidering rounding on forms to preserve the stitches parallelism, they are made quite rarely on the bulges, and in the concave part of the pattern, they are placed tightly. In the meantime, the stitches do not fall off, and they are laid tightly, without gaps.

With a soft, dense lining fabric, the gold filament may not stretch instead of piercing, but "drowns" in it. In this case, you can work without an awl, and the awl must be used when working with leather, suede and other dense, thick materials, where, to achieve a smooth cast seam, you need to pierce the points of the beginning and end of the gold stitch in advance.

The seam 'in-split' is performed similarly to the casting seam, only along the split line the gold filament is broken and pulled by the filament of the attachment (Figure 33). The result is a relief pattern. Usually, the seam "in the split" is made when sewing on cardboard or string. In a stylised plant ornament, a solid split line is usually drawn in the middle of the petals or leaves. This line is sometimes closed with a chain of frills or sequins. The "in-split" seam is used when filling in whole forms (Figure 34). In the drawing, a fragment of the pattern is filled with split lines of the same size made on the cardboard in a staggered order according to the count of the gold stitches, which are tightly adjacent to each other.

When sewing with a seam "in-attachment", gold and silver filaments, as in the previous seams, are superimposed on top of the fabric in parallel rows and attached to it with silk stitches or cotton filaments so that by arranging the stitches of the filament of the attachment, the desired pattern is achieved. Sewing is performed directly on the fabric or the flooring. In contrast to the "in-split" seam, the filament of the fastener does not tighten, does not split the stitch of the gold filament, 
but remains on the surface. The silk stitches of the attaching filament, drawing the gold filaments one after the other, form a concave line, and the non-attracted filaments create a shiny convex surface.

Depending on the tension of the filaments, a relief pattern is created. When it is necessary to more clearly depict a pattern or ornament, rather than a relief pattern, then usually a contrasting silk filament is attached. The fastening stitch is doubled or even tripled, without strongly attracting the gold filament. In the meantime, the silk is visible. Also, the impression is created of a pattern embroidered with silk on a gold background. When using cardboard for flooring, a pattern is applied to it. Then it is fixed with a gold filament. When sewing "in-attachment" on the filaments or ropes flooring, the fastening is performed according to the filament count. For the correct execution of the seam "in-attachment", it is very important to first lay a gold stitch from edge to edge (one or more, depending on how many gold filaments will be captured by one stitch of the filament attached to the pattern), secure, make sure that it is laid straight, and only then attach the filament according to the pattern.

If the direction of the gold stitch is skewed, the fixing stitch will shift, and the pattern will be distorted. This procedure is done if the gold filament is not pulled strongly by the filament attached between the ropes or according to the pattern on the cardboard. The patterns made based on the seam "in-attachment" are very diverse. Stylised plant shapes are rare, mostly combinations of simple geometric shapes. This diversity of patterns used in gold embroidery is reduced to eight main groups. They have traditional names that have come down to us from ancient times.

In the patterns of "rows" or "oblique row", the stitches of the fastening filament are arranged so that they form parallel diagonal lines (Nosan, 2009). Depending on how many gold filaments are captured with one stitch and how thick the rope or filament of the flooring is, the angle of inclination of the "oblique row" changes. When sewing on cardboard, the gold filament is attached according to the applied pattern. When sewing on a string, it is done according to the number of filaments (Figure 35).

"Fence", or "hoof", is a pattern in the form of a broken line or zigzag. The sharpness of the zigzag, as in the previous pattern, depends on the number of gold filaments captured by one stitch and on the thickness of the filaments or ropes of the flooring. The sharper the angle, the more graceful the zigzag (Figure 30).

The pattern 'money' consists of the same zigzags, but in the "fence", they are parallel to each other, and in the 'money', they are made up of the points of the corners. It is better to start the attachment with a stitch that defines the shape, in this case, the junction of the corners (Figure 37).

"Berry" pattern is a regular one in a cage (Figure 38). "Adjustable Cage" is the same pattern "berry", only the cells are divided by stripes (Figure 39). "Stalk with a Berry" is the traditional complex name of a simple rare braid consisting of straight stripes. This pattern is found on ancient Russian sewing monuments mainly in a diagonal design, i.e., the given pattern is rotated by 45 degrees (Figure 40).

"Klopets", "klopchik", "matting" is the way when the gold filament is fixed in a staggered order (Figure 41). To make the pattern, horizontal parallel lines are evenly applied to the cardboard, or the filaments of the flooring are sewn on the fabric and the fastening is carried out according to the number of filaments (Nosan, 2006). "Klopchik" is mainly in two, three, four filaments. Depending on how many gold filaments are captured, the width of the braid strips changes. 
"Feathers" is a "berry" kind, the cells of which are divided by parallel horizontal lines into triangles. Most often used for embroidery of the wings of angels (Figure 42).

Each of these pattern groups includes several complicated variants, e.g., "simple money", "money with a berry", "money in four cells" or "berry with one stitch", "berry with a cross", "double berry", etc. Some patterns cannot be attributed to any of these groups. The gold filament in them is fixed with stitches of the filament attached without a specific pattern. This technique is called "free attachment".

In ancient monuments of liturgical sewing, there is a rather rare "double complex seam" (Figure 43), which began to be used in Russia at the late 15th century in the grand-ducal workshop with the appearance of Elena Voloshanka, the wife of the son of Ivan the Third, the daughter of the powerful Moldavian ruler Stephen the Great. To make a double complex seam, first, the filaments of uncoiled silk are vertically superimposed. Then they are overlapped horizontally with twisted silk filaments attached with small stitches of the fastener in a staggered order between the parted lower filaments. This seam did not receive further significant continuation and was rarely used by Russian craftsmen.

Modern gold seamstresses use all the described types of seams and many traditional patterns in their works. The combination of the 'casting' seam with others and the use of various floorings open great opportunities for creating a rich and diverse texture of embroidery. Torzhok gold seamstresses have kept the secrets of performing many ancient seams, and some long-forgotten ones have been restored.

"Broading" seam is performed on cardboard or string, using the seam "in-split" (Figure 44). The "broading" seam is like brickwork: the split lines are staggered. It is like the 'klopets' seam. When performing a seam on cardboard, the split line is pre-pierced with an awl and cleaned.

"Goose" seam is also performed on cardboard or string (Figure 45). The form of cardboard is drawn evenly in horizontal parallel lines with $2.5 \mathrm{~mm}$ from each other, using a seam "in-split" through the line and through the filament (one filament is pulled). This is followed by a staggering move again through the line and the filament. Similarly, the seam with the flooring is performed "on a string".

Wavy seam, "samite sewing", seam "on samite work" refer to one seam, which is a soft, embossed, looped texture (Manushina, 1983). To achieve convexity, a thick sliding cord with an undefined twist, a round wire with a braid or thin tubes are used. The selected material is cut into segments and attached to the top of the form. This seam is sewn without cardboard and flooring (Figure 46). The lengths of the cord are placed at equal distances from each other. The gold filament is laid in the shape across the flooring and attached in the gaps between the cords. At the same time, the line of attachment must be smooth and clear. At the end of sewing, the cord is pulled out, and the gold filament retains a voluminous, wavy shape. For this seam, it is better to use a twisted gold filament. When performing it, you need to make sure that it does not unwind. In ancient times, this seam was called "for samite work", "samite sewing". For its implementation, a needle attached to form loops was used and then pulled out. Such loops often covered only the contour of the ornament, sewn with silk or gold, so in the inventories, the expression "sewing on the edges of the samite gold" was often found.

"Basket" seam is cut out of cardboard, pasted on the fabric and covered with long stitches with gold filament by the technique of cast seam over the entire shape. Then the gold filament is intertwined with a 
coloured (contrasting) or silver filament in a staggered order according to the number of filaments (Figure 47). On the wrong side, the coloured filament goes in a circle (double-sided smooth). The size of the cells depends on the number of filaments laid. It is sewn under tension. The seam on a cord (rope), or a smooth roller-the seam, is used as a contour (Figure 48). Usually, it is sewed the contours of fragments of the headdress omament and decorated the embroidery instead of a twisted gold cord performed on the principle of a 'casting' seam. When sewing round shapes, the stitches on the inside of the fragment are laid more tightly than on the outside to obtain uniform sewing. The thicker the flooring cord, the more pronounced the seam is.

Thus, the gold embroidery of girls' and women's headdresses, presented in the Local History Museum of Karelia, is a bright, original art that attracts a specific expressiveness - the magic of sunlight. Gold embroidery is a rather complex type of embroidery. It requires special attention, painstaking and accuracy. The art of gold embroidery was not owned by every craftswoman. The ability to embroider with gold was passed down in the family, from generation to generation. It was taught in parochial schools, monasteries of Kargopol, reaching the highest level. The brilliant, festive headdresses and ornaments of the masters of the Karelian Russian North have always been luxury items and an indicator of the wealth of their owner.

\section{Conclusion}

Thus, the research activity on the revival, preservation and application of ancient technologies of embroidery of women's headdresses in the traditional applied art of Karelia is of great interest to researchers, as a storehouse of the diverse cultural heritage of Karelia, being a unique expression of the achievements of humanity, serves as an indispensable source of spiritual and intellectual wealth. In the process of research analysis of the state of artistic heritage, festive women's headdresses, their aesthetic content of forms, laws and rules of compositional solutions, ornamentation, embroidery techniques, fabrics, designs of shapes, sizes, patterns, colours; taking into account the traditions and professional training in this field, regionalhistorical, informational-informing, instructive-practical, artistic-technological, practice-oriented research methods are used in the museum, which provides a unique opportunity to study authentic works of traditional applied art in the field of artistic embroidery.

Presented in the local history museums of the republic, samples of folk clothing and headdresses are a vivid illustration of the features of traditional everyday culture. These masterpieces of folklife are an important component of the general culture of the peoples living on the territory of Karelia. The folk costume is an inexhaustible source of creativity. It concentrates an infinite wealth of ideas, which can be achieved by a diversity of forms, unusual design solutions of headdresses as a whole and their elements, colourful embroidery. The richness of forms and unexpected solutions give us the hats presented in the article. Original forms of structures and unusual compositions allow to meaningfully transform the sources and find expressive, complete, imaginative artistic solutions, which significantly contributes to the renewal and enrichment of modern products. Ancient, national headdresses are presented as an example of original forms, designs and interesting ornamental solutions. They are widely represented by the combination of different materials and textures. The headdresses most clearly show the features of national identity, which can serve to create new compositions of folk 
national colour in the future. When developing modern hats, you need to consider the fact that such products can be used in creating a wedding ensemble or evening dress.

The artist who creates modern clothing does not copy the forms of folk costume and embroidery but creatively reworking them, achieves expressiveness and imagery of the solution.

The theoretical significance of the research is that it contributes to the theory and methodology of professional education and professional competencies in each specific art form in the process of teaching the technology of artistic embroidery and improving the skill of artistic embroidery. Summing up all the above, it can note that the article collects, analyzes and summarizes the material on northern headdresses, which can serve as an invaluable creative source for the work of modern artists and designers of clothing.

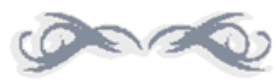

\section{References:}

Bozheva, P.P. (2008). Russian ornament in embroidery: tradition and modernity. Moscow: Art School of Applied Art. (in Russian).

Fersman, A.E. (1954). Stories about gems. Leningrad. (in Russian).

Grigorieva, G.A. (2002). Russian North through the eyes of a restorer. Fabrics, clotbing. Arkhangelsk. (in Russian)

Historical and legal acts of the Olonetsky Krai. (2016) Olonetsky gubernskie vedomosti 1850. Retrieved October 3, 2020, from http://www.kondopoga.ru/ terr/7terr01.php (in Russian)

Khrebtov, A.A. (2017). The situation in the pearl industry in Russia. Retrieved November 1, 2020, from http://www.kondopoga.ru/ terr/7terr01.php (in Russian)

Kosmenko, A.P. (1990). Karelian folk art. (in Russian). Petrozavodsk.

Manushina, T. (1983). Sewing of ancient Russia. Zagorsky Museum. Moscow: Soviet Russia. (in Russian).

Nosan, T.M. (2009). Karelian pearl. A.I. Herzen RSPU Izvestiya, 94, 178-181. St. Petersburg. (in Russian).

Nosan, T.M. (2006). Women's headdresses in the work of masters of Karelia: An educational and methodological guide. Petrozavodsk. (in Russian)

Olonetsky gubernskie vedomosti. 1897 (2016). Retrieved October 6, 2020, from http://www.kondopoga.ru/_terr/7terr01.php (in Russian)

Pearl... Ancient decoration of Northern Russia. Retrieved October 6, 2020, from https://www.perunica.ru/tradicii/10210-zhemchug-starinnoe-ukrashenie-severnojrusi.html (in Russian)

Sosnina, N., \& Shangina, I. (1998). Russian traditional costume. Illustrated Encyclopedia. St Petersburg: Iskusstvo. (in Russian)

Women's folk costume in Russia of the 18th and 20th centuries (2013). Almanac, 405. St. Petersburg: Palac Editions. (in Russian) 


\section{Appendix}

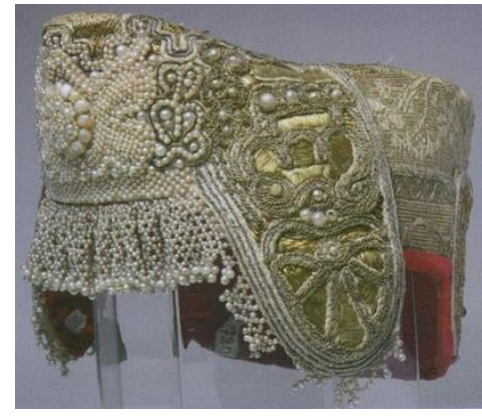

Figure 1. Kargopol kokoshnik. The second half of the 19th century. Olonets province, Kargopol uyezd. Glass beads, beads, river pearls, mother-ofpearl dies, gold-plated spun silver, beat, gold cord, calico, gold embroidery "in-attachment", sewing with beads and pearls.

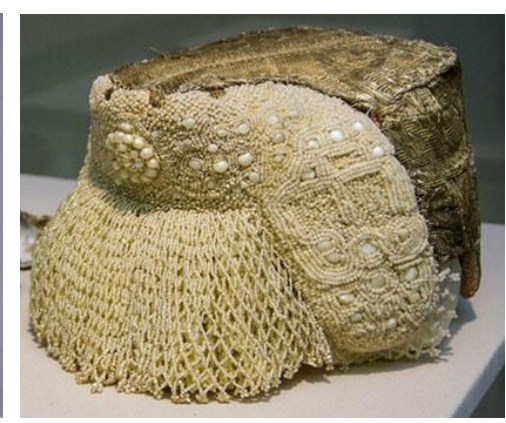

Figure 2. Kargopol kokoshnik. The second half of the 18th century.

Olonets province, Kargopol uyezd. Glass beads, beads, river pearls, mother-of-pearl dies, gold-plated spun silver, beat, gold cord, calico, gold embroidery "in-attachment", sewing with beads and pearls.

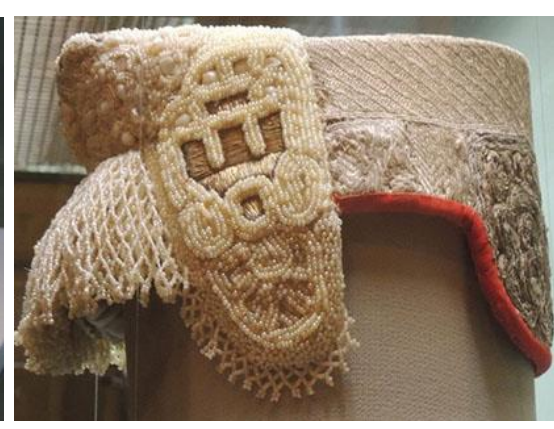

Figure 3. Kargopol kokoshnik. The second half of the 19th century.

Olonets province, Kargopol uyezd.

Glass beads, beads, river pearls, mother-of-pearl dies, gold-plated spun silver, beat, gold cord, calico, gold embroidery "in-attachment", sewing with beads and pearls.

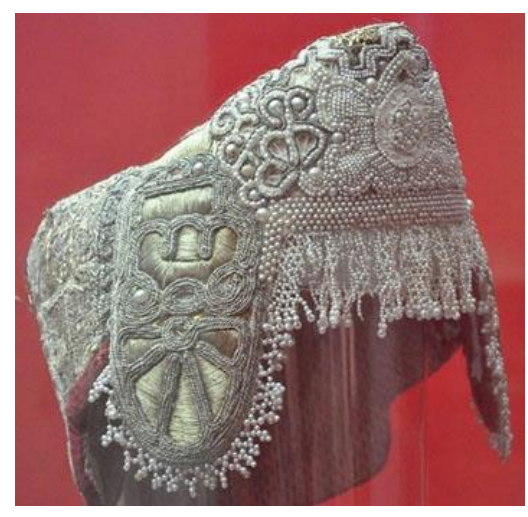

Figure 4. Ancient women's headdress kokoshnik. Kargopol uyezd, Olonets province. Early 19th century. Gold braid, river pearls, beads, mother-ofpearl dies, white lace, gold threads; knitting. Embroidery with beads, pearls. Gold embroidery "inattachment"

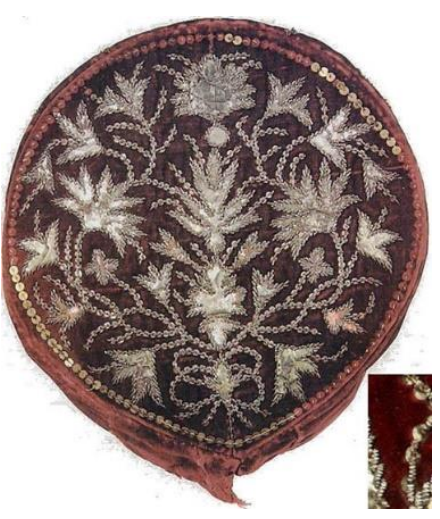

Figure 5. Women's headdress kokoshnik. Povenetsky uyezd. The first half of the 19th century. Velvet, braid.

Embroidery with colored foil, cannetille, spangles

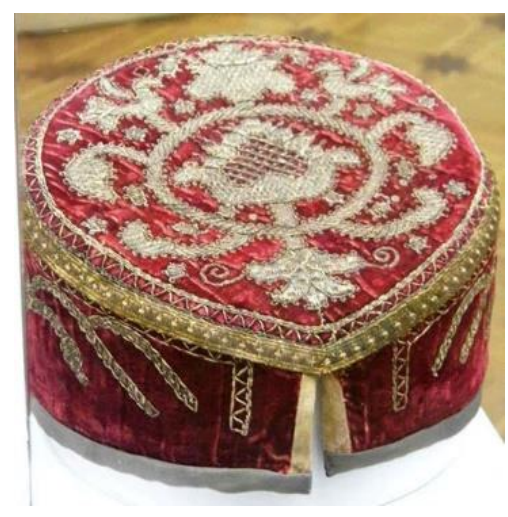

Figure 6. Women's headdress kokoshnik. 19th century. Olonets province. Damask, gold-plated spun silver, gold cord, braid, silk braid, linen knockout. Gold embroidery "in-attachment" 


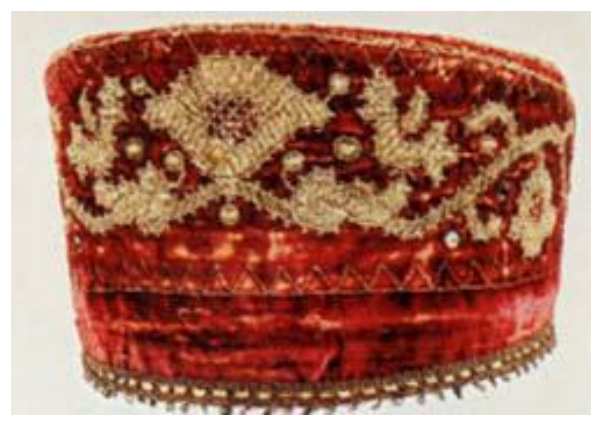

Figure 7. Women's headdress kokoshnik. 19th century. Olonets province, Vytegorsk uyezd, Vytegorsk volost. Velvet, gold-plated spun silver, gold cord, cotton printed fabric (knockout), silk braid, tinsel braid. Gold embroidery "in-attachment"

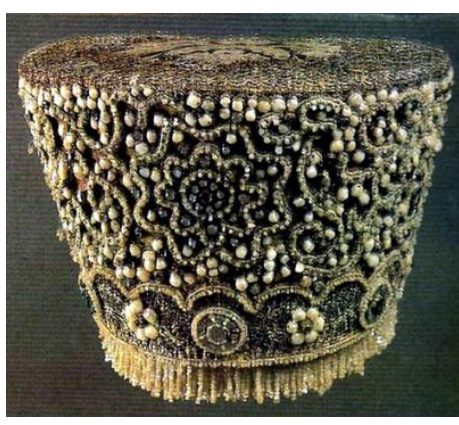

Figure 8. Women's headdresskokoshnik on a solid base with a hem made of chopped motherof-pearl. 19th century. Olonets province. Cardboard, shtof, canvas (lining), metal lace, mother of pearl, pearls, sewing, knitting, metal thread, glass in cufflinks and sockets

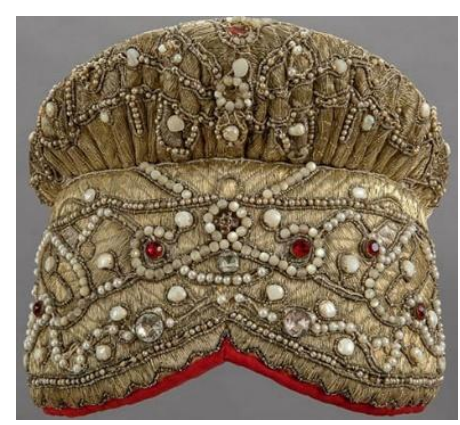

Figure 9. Festive women's headdress - kokoshnik assembly type. Early 19th century.

Arkhangelsk province. Spun gold-silver threads, gold, chopped mother-of-pearl, faceted glass, pearls, gilded foil is pierced with rounded prongs of river pearls. Lived in the villages along the Mezen River
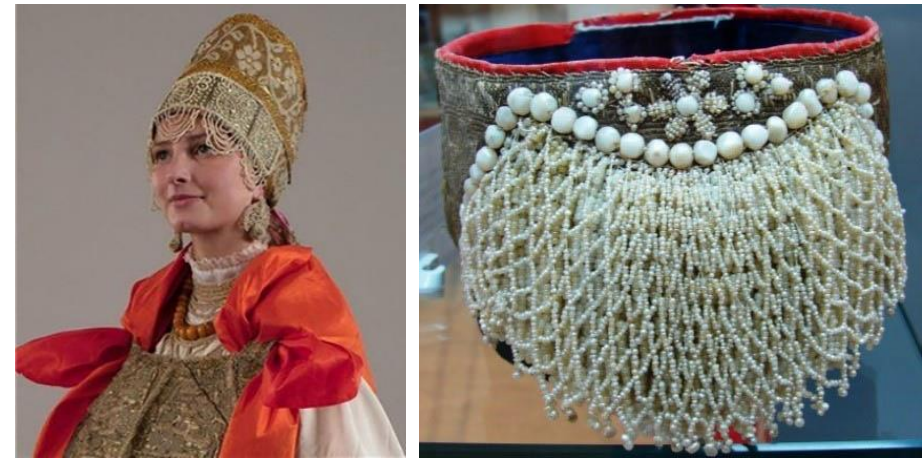

Figure 10. Dressing, dressing Figure 11. Bandaging. Late 19th and with silk ribbon late 19th century. Olonets province.

Braid, foil, cardboard, chintz, glass beads, beads, mother-of-pearl dies early 20th century. Olonets province, Kargopol uyezd, Usachevsky volost. Braid, river pearls, beads, mother-ofpearl dies, calico, cardboard; Gold embroidery, embroidery with pearls and beads

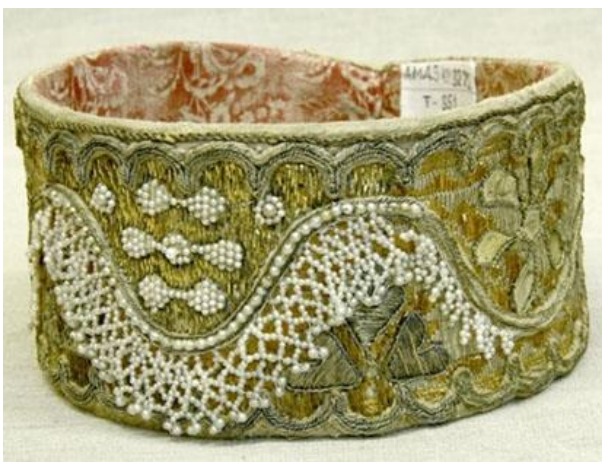

Figure 12. Bandaging, Late 19th century, Olonets province, Kargopol uyezd. Under the bottom, the grid consists of several pearl collections. Sewing with pearls, beads, gold embroidery on a high card "inattachement" 


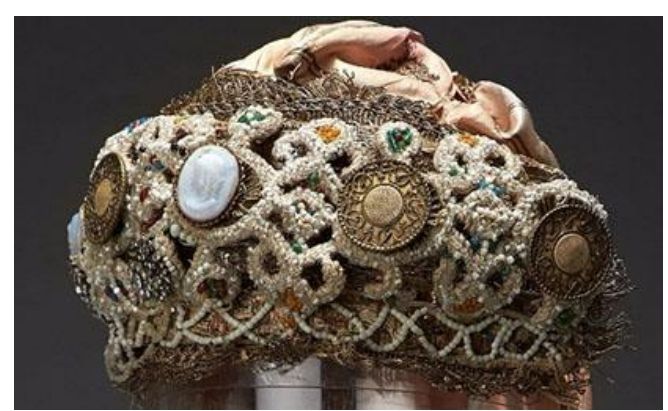

Figure 13. 'Konura' or koruna - a maiden wedding headdress. Late 19th century. Vologda province, Solvychegorsk. Cardboard, calico (lining), braid, braid, metal fringe, glass inserts, beads, beads, sewing, knitting, glass and metal brooches, silk ribbons

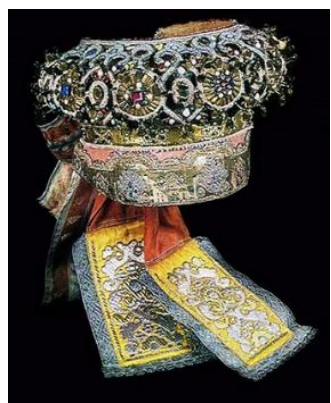

Figure 14. 'Konura' or koruna - a maiden wedding headdress. Late 19th century. Vologda province, Solvychegorsk. Cardboard, calico (lining), braid, braid, metal fringe, glass inserts, beads, beads, sewing, knitting, glass and metal brooches, silk ribbons

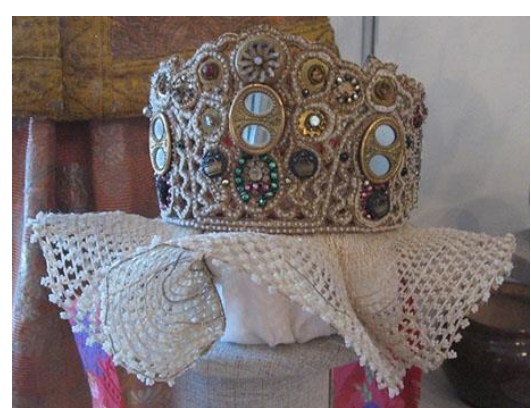

Figure 15. 'Crown' is a girl's festive headdress. Olonets province, Pudozhsky district, 19 th century. Gold thread, beads, glass beads, colored glass, mother-of-pearl cardboard; mesh podniz. Casting pearls on horsehair, ribbon

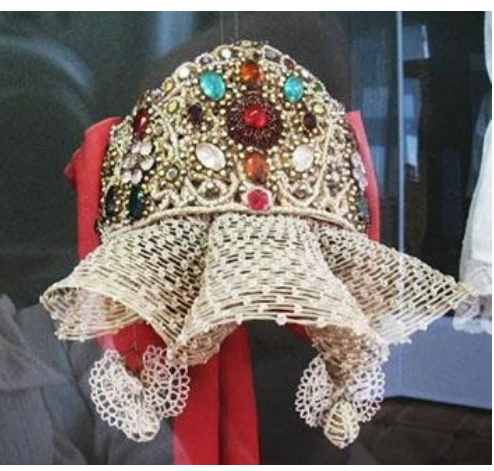

Figure 16. 'Crown' is a girl's festive headdress. Olonets province,

Pudozhsky district, 19th century. Gold thread, beads, glass beads, colored glass, mother-of-pearl, cardboard; mesh-under the bottom. Knitting pearls on horsehair, ribbon, "butterfly" earrings

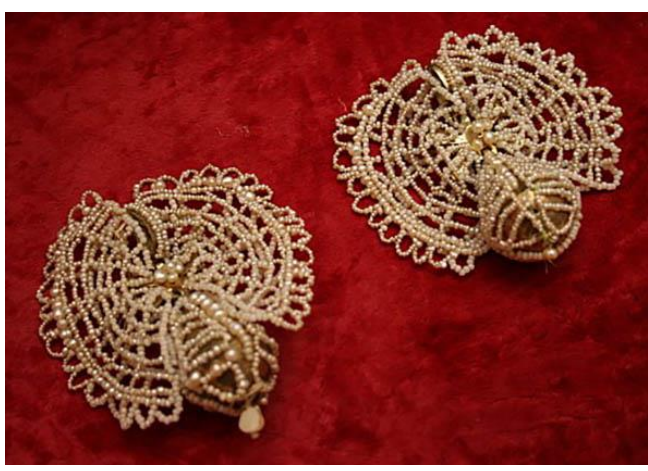

Figure 17. "Butterfly" earrings, 19th century. Olonets province, Pudozh district. Beads, chopped mother of pearl, metal, casting river pearls on horsehair

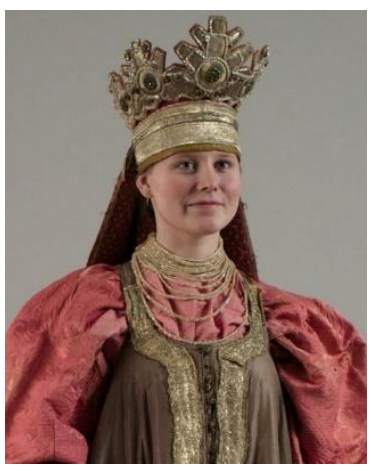

Figure 18. "Pochelok" (Podchelok) - also called the "crown" with five raysfences. The second half of the 18 th century.

Novgorod province.

Cardboard, paper, gold

threads, sewing 'inattachment', tinsels, glass.

Ribbons for the crown: brocade, silk, gold embroidery 


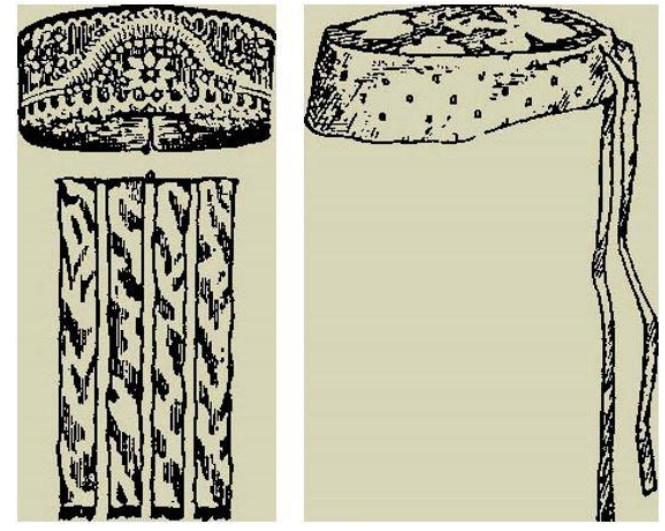

Figure 19. "Circle" and "flags" of the betrothed girl Olonets province, Kargopol uyezd 18th century. Wool, silk, linen, cotton fabrics, printed fabrics, paper, linen, beads, tinsels. Embroidery with beads
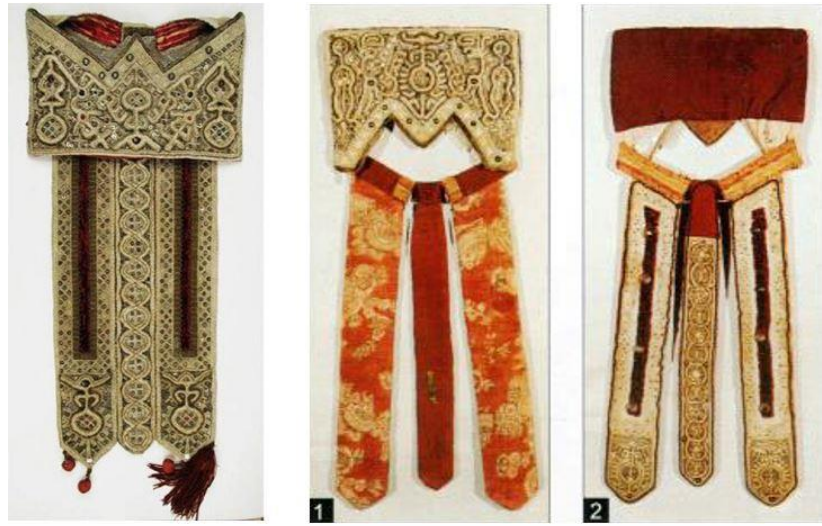

Figure 20. "Podcholok" - a festive maiden headdress of the 18th century Olonets province, Kargopol uyezd. Wool, silk, linen and cotton fabrics, paper, linen, beads, tinsels, metal, glass buttons, strung pearls and beads

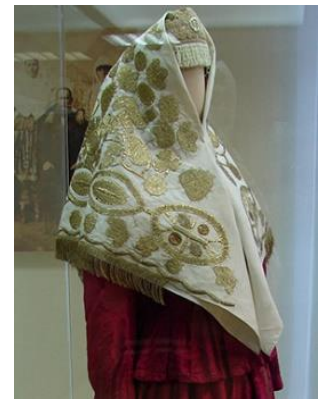

Figure 21. The golden handkerchief of the 19th century. Olonets province, Kargopol uyezd, Lodyginsky volost. Cotton cloth, paper, gold-plated spun silver, lace, silk and cotton threads, fringe; gold threads "in-attachment", vestibule seams
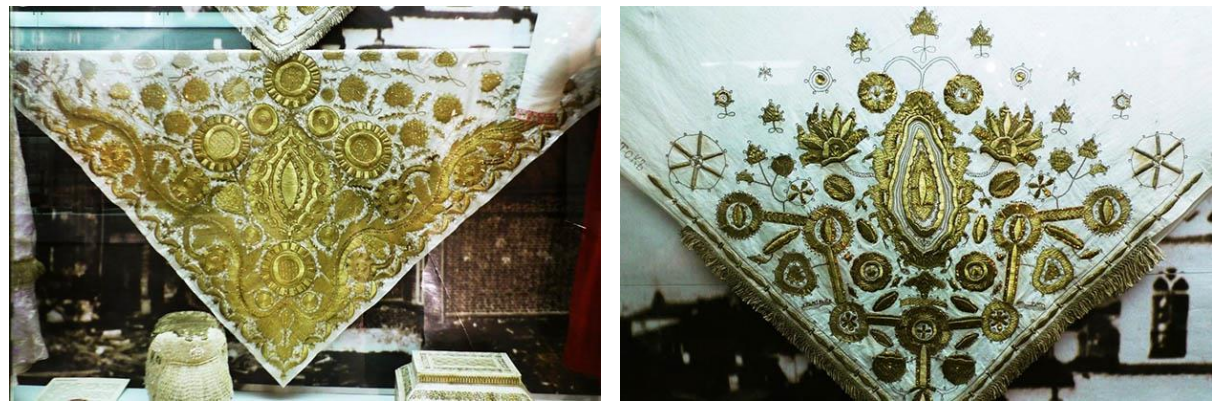

Figure 22. Golden handkerchief of the 19th Figure 23. Handkerchief golden end of the century. Olonets province, Kargopol uyezd,

Lodygino volost. Mitkal, gold threads, paper. Gold embroidery "in-attachment", vestibule seams
19 th century. Olonets province, Kargopol uyezd. Cotton canvas, gold-plated spun silver and gold, paper. Gold embroidery "in-attachment", vestibule seams 


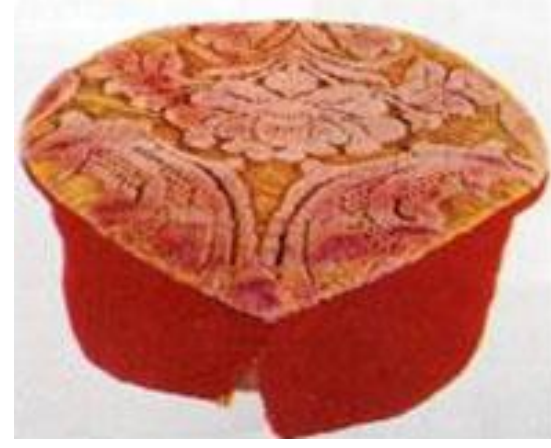

Figure 24. Povoynik The beginning of the 20th century. Arkhangelsk province, Mezensky uyezd. Yurom parish, the village of Malaya Nisogora. Tinsel brocade, kumach, calico

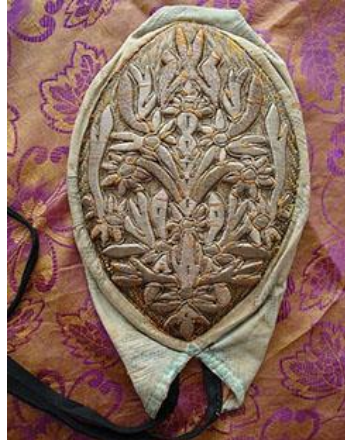

Figure 25. Povoynik. The second half of the 19th century.

Arkhangelsk province, Kem uyezd, Vygostrov village. Velvet, spun silver, river pearls, cardboard, wool blend. Gold embroidery "inattachment" on the high map

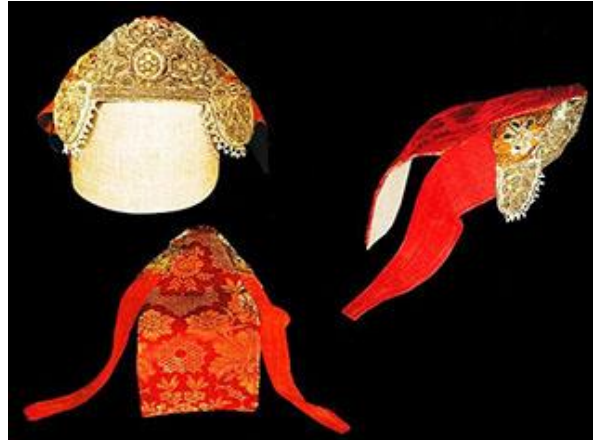

Figure 26. "Magpie". 19th century. Olonets province, Kargopol uyezd. Silk fabric, pestryad, linen cloth, spun silver, gold cord, thread, foil, pearls, beads, glass beads, gold embroidery "in-attachment", embroidery with beads

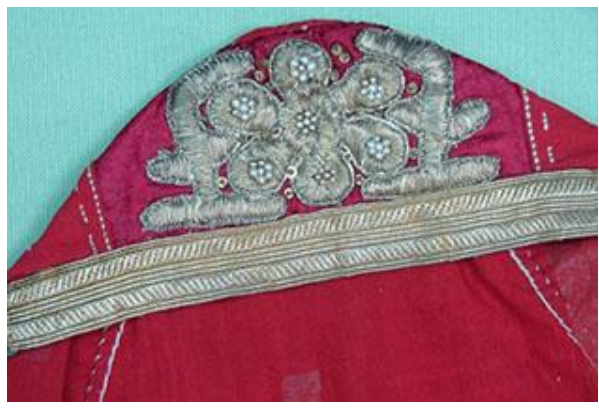

Figure 27. "Magpie". 19th century. Olonets province, Kargopol uyezd. Calico, shtof,

Chinese, braid, gold-plated spun silver, gold cord, glass beads, metal tinsels; hand sewing, gold embroidery "in-attachment", sewing with beads

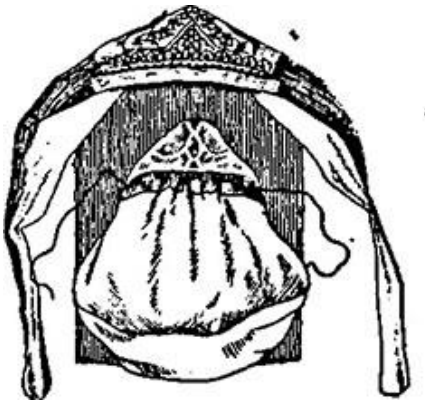

Figure 28. 'Magpie' with sderikha. 19th century.

Olonets province, Kargopol uyezd. Calico, silk, velvet, canvas or calico lining, silver or gold threads, beads, beads
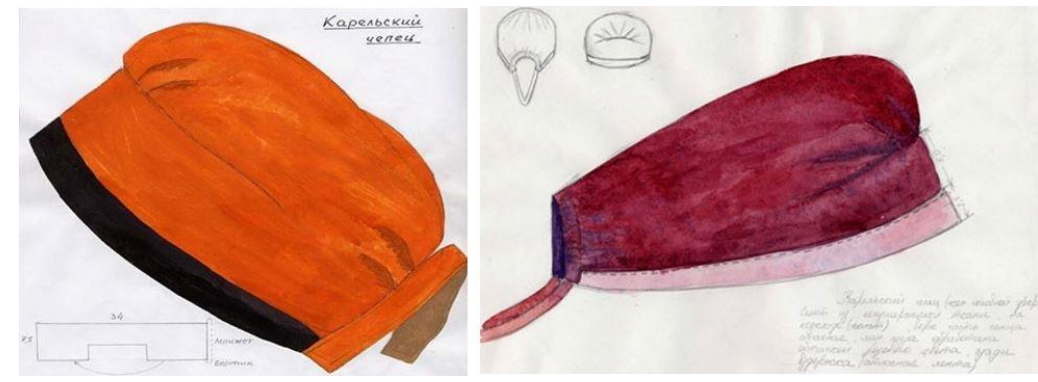

Figure 29. Karelian caps of the beginning of the 20th century. Olonets province, Kargopol uyezd 


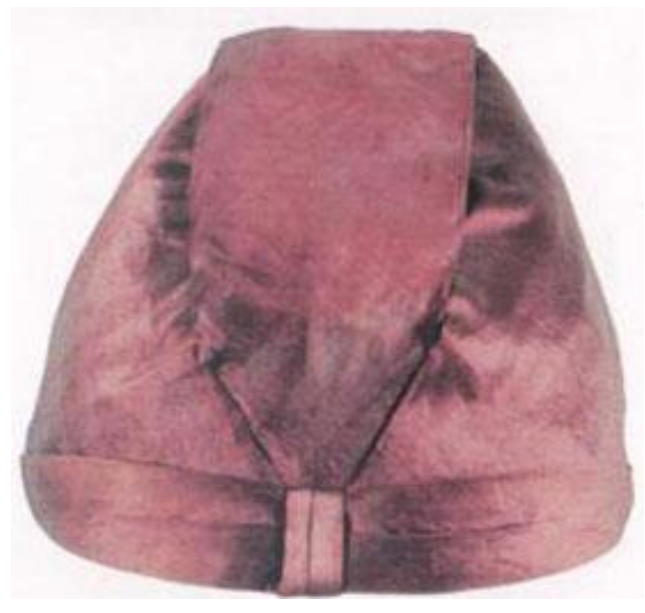

Figure 30. Skolok. Late 19th century. Arkhangelsk province, Kholmogor uyezd, Bystrokursk volst, Pogost village. Dvoelikaya Bystrokursk volst, Pogost village.
taffeta, mitkal, paper

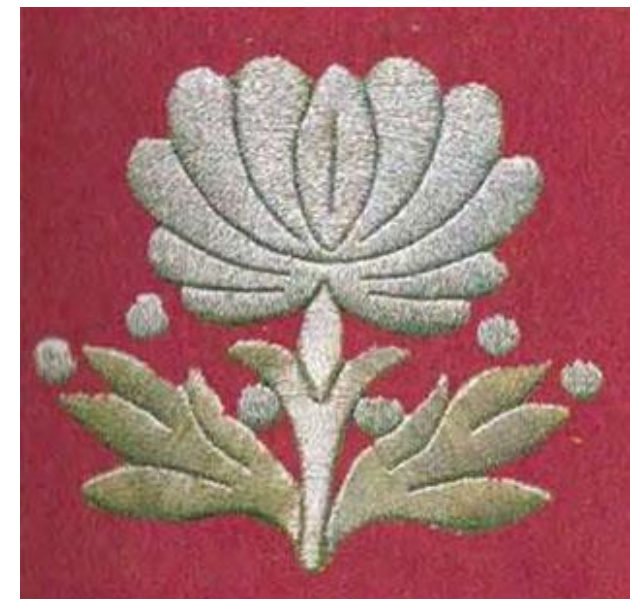

Figure 31. "Casting" seam

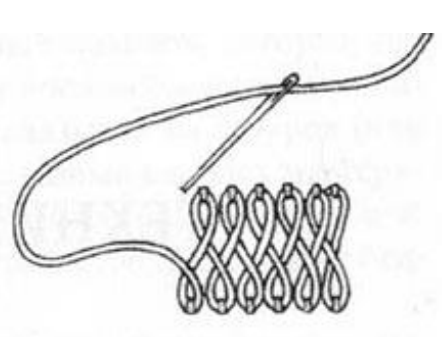

Figure 32. Seam "in-attachment"

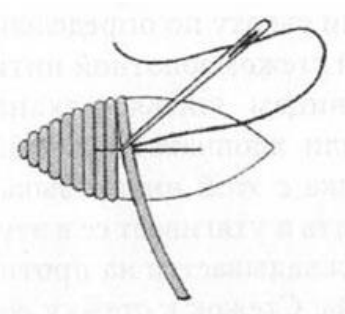

Figure 33. Seam "in-split"

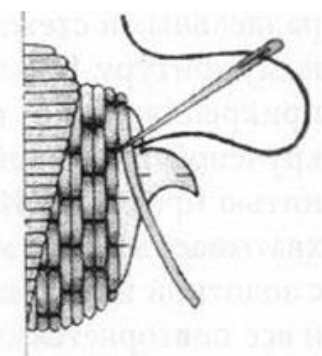

Figure 34. Seam "in-split"

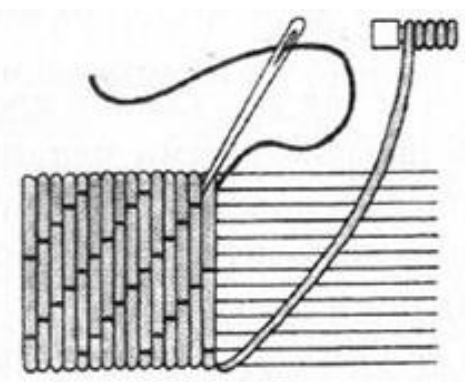

Figure 35. Seam "Rows"

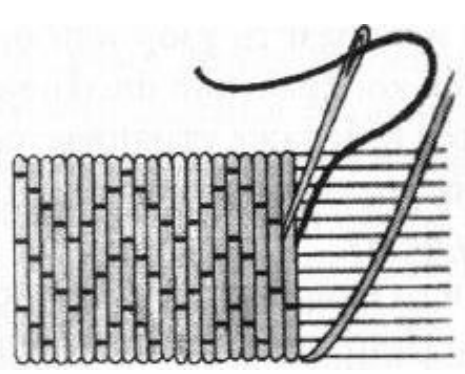

Figure 36. Seam "Fence" 


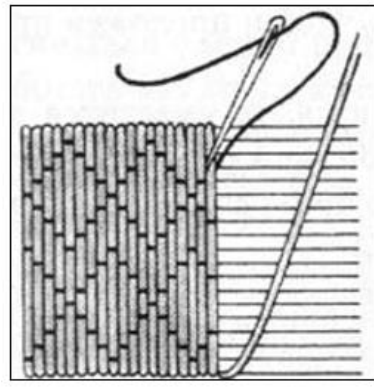

Figure 37. Seam "Money"

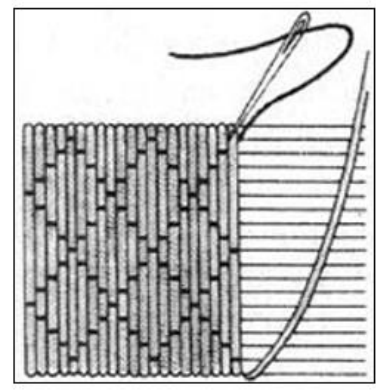

Figure 38. Seam "Berry"

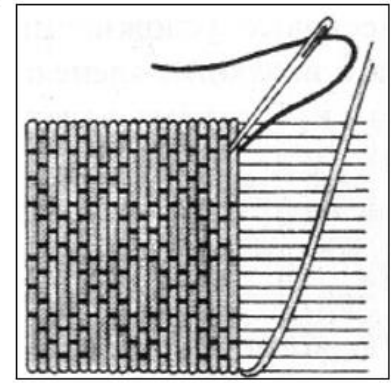

Figure 39. Seam "Adjustable cell"

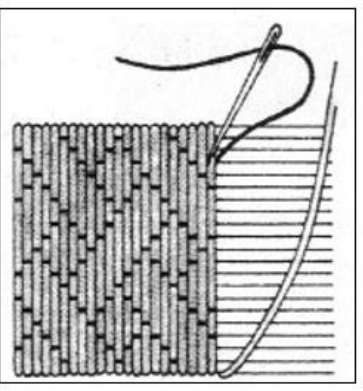

Figure 40. Seam "Stalk with a Berry"

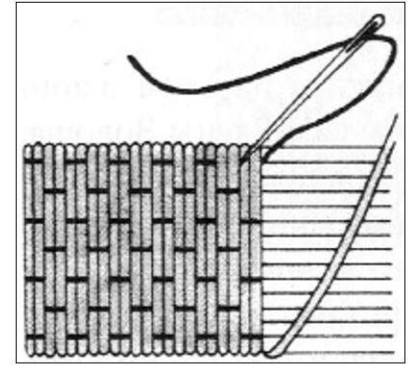

Figure 41. Seam “Klopets”

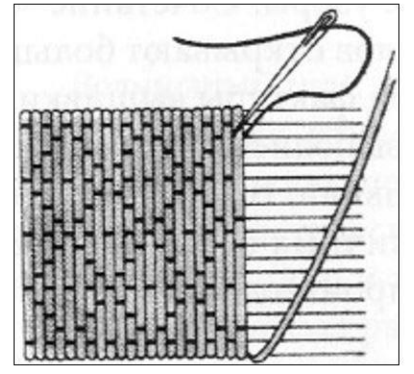

Figure 42. Seam "Feathers"

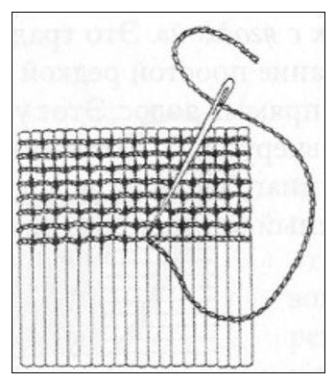

Figure 43. "Double Complex Seam"

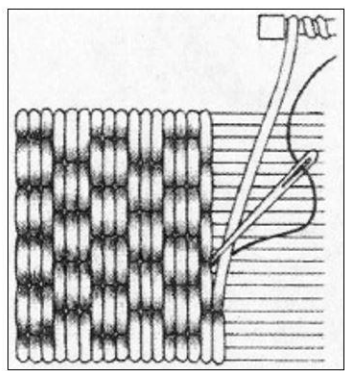

Figure 44. Womanish seam

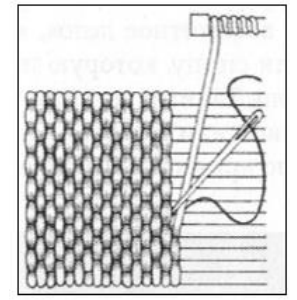

Figure 45. "Goose" seam

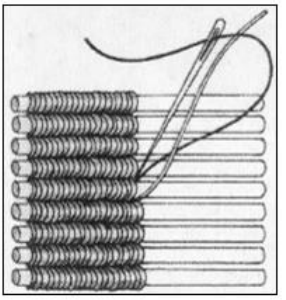

Figure 46. Wavy seam of Aksamite Sewing

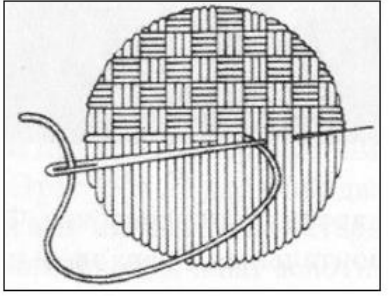

Figure 47. "Basket" seam

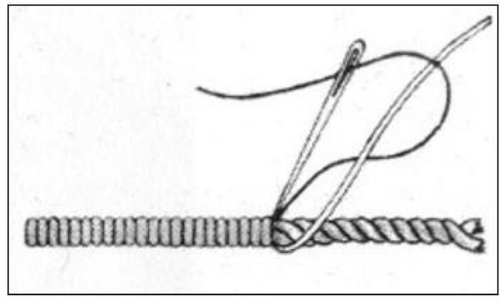

Figure 48. Seam by "cord, (string)" or "smooth roller" 